\title{
INFLUENCE OF PREGNANCY ON SOME ERYTHROCYTE BIOCHEMICAL PROFILES IN THE RABBITS
}

\author{
OZEGBE, P.C. \\ Department of Veterinary Anatomy, University of Ibadan, Ibadan, Nigeria.
}

\begin{abstract}
One billion erythrocytes lysate samples obtained from pregnant (28-day old) and non-pregnant groups or New Zealand white Chinchilla rabbits (eight rabbits per group) were analysed to determine the influence of pregnancy on the profile of some of the intracellular electrolytes, enzymes, lipids, proteins and rnetabolites. The intracellular concentrations of sodium $\left(\mathrm{Na}^{+}\right)$, Bicarbonate $\left(\mathrm{HCO}_{3}\right)$, Alanine amino transferase $(\mathrm{ALT}, \mathrm{EC}$ 2.6.1.1), Aspartate amino transferase (AST, EC 2.6.1.1). Gamma glutamyl transferase (GGT EC 2.3.2.2) and triglycerides were significantly Increased $(P<0.01)$ in the pregnant group when compared to the nonpregnant group. The levels of potassium $\left(K^{+}\right)$, Sodium-Potassium ratio $\left(\mathrm{Na}^{+} / \mathrm{K}^{+}\right.$ratio), cholesterol creatinine and blood urea nitrogen (BUN) alkaline phosphatase (AP, EC 3.1.3.1), total protein and albumin were not significantly altered during pregnancy. Pregnancy altered the metabolism of erythrocytes in the rabbits.
\end{abstract}

Key Words: Erythrocyte, biochemistry/, pregnancy, rabbit.

E-Mail for correspondence: uivetmednasteinctig.net

\section{INTRODUCTION}

There are published reports of heamodilution and alterations in renal plasma flow, glomerular filtration rate, plasma volume as well as gastro-intestinal absorption efficiency during pregnancy (Sims and Krantz, 1958; Hytten and Leitch, 1984: MacDonald and Good, 1971b). These observed changes during pregnancy further resulted in alterations in hematological and plasma biochemical profiles (MacDonald and Good, 1971a,b; Rowland et al, 1975; Felbinger, 1987; Junid and Krad, 1987; Vihan and Rai, 1987; Allard et al, 1989). But data on the intracellular biochemical profiles of erythrocytes of pregnant rabbits during health and disease are sparse.

Mulei et al (1988) and Mulei and Daniel (1990) determined the concentrations of some erythrocyte electrolytes in the dairy cows during late pregnancy and early lactation. Evans et al (1963) reported the effects of experimentally induced anaemia in the sheep on some erythrocyte intracellular indices. Since late pregnancy is associated with decreas ed Packed Cell Volume and red blood cells counts, similar to the situation obtained during lactation as well as anaemia caused by experimental Heammonchus cotilortus infection, it could be possible that the intracellular clinical chemical profile of erythrocyte is influenced by the physiological anaemia associated with pregnancy.

This study was designed to determine the influence of pregnancy on erythrocyte biochemistry. The ba data so obtained could further define the adaptations that occur during pregnancy.

\section{MATERIALS AND METHODS}

Non-pregnant and 28-day old pregnant New Zealand White Chinchilla rabbits (8 rabbits per group) of similar age were used. The animals were selected from a colony at the Experimental Animal Unit, Faculty of Veterinary Medicine, University of Ibadan, Ibadan,
Nigeria. Feed (Ladokun rabbit pellets) and water were supplied ad libitum.

\section{Sample collection}

Maternal blood sample, obtained by ear vein puncture, was drawn into a lithium heparin coated tube.

\section{Preparation of lysate for enzyme assays}

The method of Fairbanks and Ktee (1987) was used in preparing the lysate. One billion $\left(10^{9}\right)$ saline-washed and thoroughly mixed erythrocytes were diluted with $2 \mathrm{~m} \mathrm{I}$ of Na2EDTA-2-mercaptoethanol.

\section{Preparation of lysate for some clinical chemical parameters assays}

The haemolysate was prepared as described by Wilson and Dixon (1991). The erythrocyte count of the lithium chloride-washed cells was determined as described by Jam (1986), after thorough mixing, $10^{8}$ red blood cells (rbc) were thereafter put into $2 \mathrm{ml}$ of deionized water and mixed in a vortex machine.

\section{Sample analysis}

$\mathrm{Na}^{+}$and $\mathrm{K}^{+}$concentrations were determined using the flame photometer (Corning model 400, Corning Scientific Ltd, England).. The haemolvsates were diluted with deionised water in the atio of 1:100 for $\mathrm{Na}$ and 1:50 for P Urea nitrogen, creatinine and triglycerides profiles were determined as described by Toro and Ackermann (1975) while total cholesterol was determined according to Zlarktis et al (1953).

The concentrations of erythrocyte ALT and AST were determined according to Reitman and Frankel (1957). The method of Omotainse et al (1994) was used in determining the level of AP. Statistical significance of differences between pregnant and non- pregnant groups were established by the- Students $t$ test procedure of a Statistical Analysis System Software (1988). 


\section{RESULTS}

The intra levels of $\mathrm{Na}^{+}, \mathrm{K}^{+}, \mathrm{HCO}_{3}{ }^{-}$and $\mathrm{Na} / \mathrm{K}$ ratio in pregnant and non-pregnant groups are as presented in Figures 1,2 and 3. The erythrocyte concentration of $\mathrm{Na}^{+}$ and $\mathrm{HCO}_{3}$ were significantly Increased $(\mathrm{P}<0.001)$ in the pregnant group but the Intracellular $\mathrm{K}^{+}$and $\mathrm{Na}^{+} / \mathrm{K}^{+}$value were not significantly altered

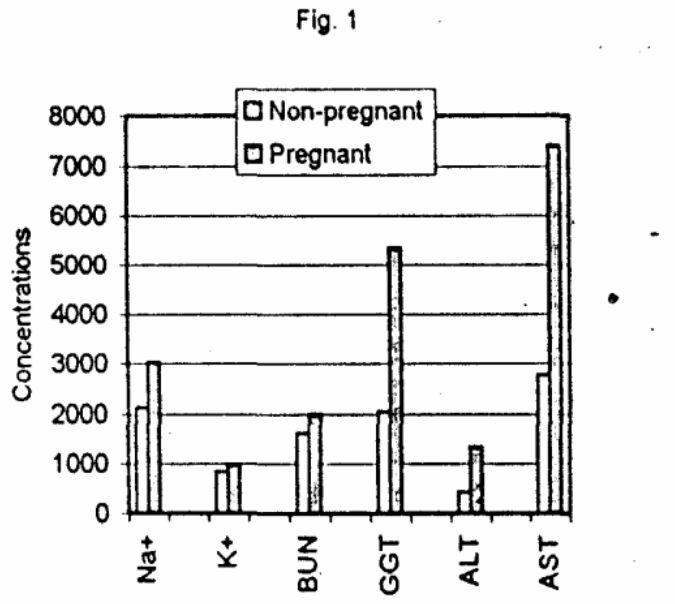

Fig. 1. Na+, K+, BUN (mmoll), GGT, ALT and AST ( $u / L$ ) concentrations in enthrocytes of pregnant and non-pregnant rabbilts.

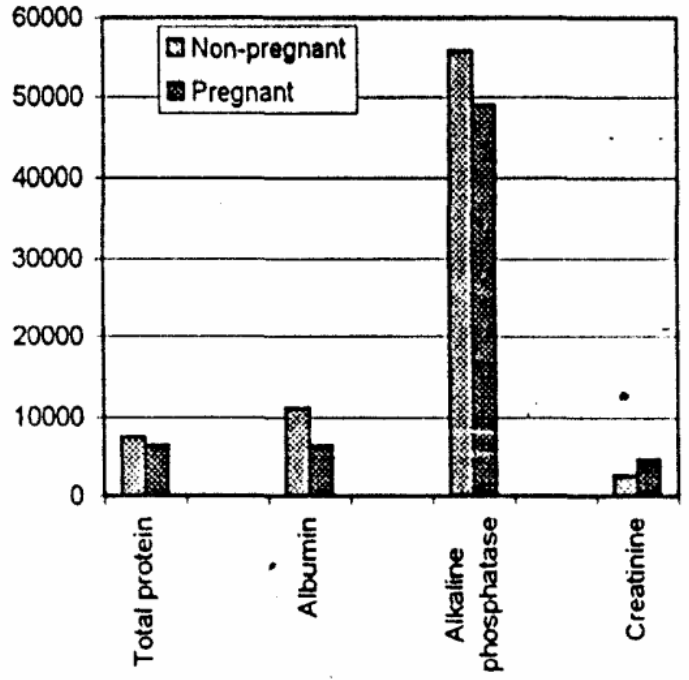

Fig. 2. Total protein ( $/ / L)$. Albumin $(g / L)$, Alkalino phosphatase $(u / L)$ and creatininelevels in orythrocytes of pregnant and nonpregnant rabbits.

The mean Intracellular concentrations of total protein, albumin BUN and creatinine fluctuated non-significantly during pregnancy. The triglycerides value was significantly $(P<0.01)$ increased during pregnancy. Intracellular level of cholesterol was not affected by pregnancy.

The effects of pregnancy on the intracellular erythrocyte concentrations of AP, ALT, AST and GGT are as presented ALT, AST and GGT were significantly increased in the pregnant group $(P<0.01)$ while AP remained stable.

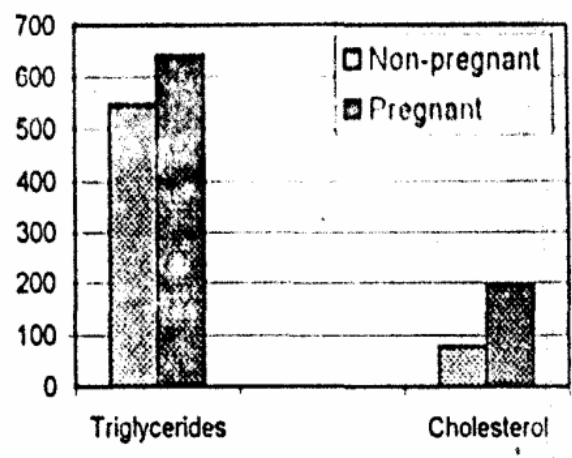

Fig. 3. Triglyceride and cholesterol levels in the enthrocytes of pregnant and non-pregnant rabbits. Both parameters are expressed as mmoll.

\section{DISCUSSION}

The significant increase in the level of intracellular $\mathrm{Na}^{+}$ in the pregnant group $(P<0.001)$ is comparable to the uniformly observed hypernatraemia during late pregnancy (Kaiser and Cummings, 1958; Rowlands et al., 1975; Kleinman and Lorenz, 1989). This late pregnancy-induced hypernatraemia maybe as a result of the particularly high aldosterone production, which promotes $\mathrm{K}^{+}$excretion and $\mathrm{Na}^{+}$reabsorption in the renal tubule, during pregnancy (Rowlands et al, 1975). The increased extra-cellular fluid (ECF) $\mathrm{Na}^{+}$will cause water to pass out of the cells which could result in Intracellular dehydration (Latner, 1975) and the associated increase in intracellular $\mathrm{Na}^{+}$concentration.

The non-significant rise in the concentration of the erythrocyte potassium accompanied by a significant rise in the $\mathrm{Na}^{+}$level could also be attributed to either physiological alteration in the balance between the rate of erythropoiesis and aging or the initial phase of the reversal, i.e. Increased EK and decreased erythrocyte $\mathrm{Na}^{+}$, during lactation as reported by Motel and Daniel (1990).

The increase In the rbc $\mathrm{Na}^{+} / \mathrm{K}^{+}$ratio observed in the pregnant group may be due to either in vivo aging (Benstein, 1959) or some degree of failure of the sodium pump mechanism (Koter et al., 1985). It could also have resulted form differences in the distribution pattern of high and low $\mathrm{K}^{+}$subjects among the experimental groups of rabbits

High progesterone levels cause hyperventilation with a consequent greater rapidity of carbon dioxide hydration in the erythrocyte (Latner, 1975). Thus, the significantly Increased erythrocyte concentration of $\mathrm{HCO}_{3}{ }^{-}$in the pregnant rabbits' group could have been a secondary effect of increased levels of hormones of pregnancy.

The increased intracellular levels of ALT, AST and GGT during pregnancy are contrary to the report findings in the plasma (Karadjole et al 1985; Felbinger, 1987, Allard et al, 1989). These alterations could have 
been a product of accelerated erythropoietic activity since young blood cells are characterized by increased activities of enzymes (Sass et al, 1964). Alternatively, it could be attributed to the intracellular dehydration induced by increased ECF Na.

The observed stability in the intracellular levels of AP, total protein and albumin could probably be as a consequent of their being required by the fetus for bone and other tissues formations. The cell membranes are generally permeable to metabolites or non-protein nitrogen (Latner, 1975) The observed increment in the intracellular concentrations of metabolites, against the reported decreased plasma levels (Brzostowski et al, 1996), could then be due to shift from the plasma to the erythrocyte by such small molecules.

\section{REFERENCES}

Allard, R.L., Carlos. A.D. and Faltin, E.C.(1989): Canine haematological changes during gestation and lactation. ('omp. Con!. Ed,,c. Pract. Vet. 19: 3-6.

Bernstein, RE. (1959): Alternations in metabolic energetics and cation transport during ageing of red cells. .1. Cli Invest. 38: 1572-1 586.

Brozostowski, H, Milewski, S; Wasilewska, A and Tanski, Z. (1996): The Influence of the reproductive cycle on levels of some metabolism indices in the ewes. Arch. Vet. Polonicum 35: 53-62.

Evans, J.V; Blunt, M.H. and Southcott, W.H. (1963): The effect of infection with Haemonchus contortus on the sodium and potassium concentrations in erythrocytes and plasma in sheep of different haemoglobin types. Aiis/m/ian J. Agric. Res. 14: 549558

Fairbanks, V.F. and Klee, G.G. (1987): Biochemical Aspects of Haematology. In: N.W. Tietz (ed.): Clinical Chemistry, W.B. Saunders Co., Philadelphia pp 789824.

Felbinger, V. (1987): Selected serum constituent in pregnant and lactating, thorough bred mares. Israeli. Vet. Med. 43: 96-103.

Hytten, F.E. and Leitch, 1. (1964): The Physiology of Human Pregnancy. Blackwell, Orford.

Jam, N.C. (1986): Schalm's Veterinary Haematology, Lea and Ferbiger, Philadelphia.

Junid, M. and Krad, FI. (1987): Untersuchung einiger blutparameter ausserhaib and wahrend der trachtigkeit bei milchrindern (Hoistein-Friesian) in Syrien (Kurzmitteilong). Mona/e.v/,. Vet. Med. 42: 700-701.

Kaiser, 1.H. and Cummings, J.N. (1958): Plasma electrolytes of the pregnant. ewe and fetal lamb. Arn.J Physio/. 193: 627-633.

Karadjole, I., Krizanovic, D; Mikulec, K; Rako, A. and Uhitil, S. (1985): Aktivnost enzima alkalue fosfotaze i transaminaza (GOT i OPT) u serurnu ovaca tijekom tactcije. Vet. Arhiv* 55 (Suppl.) 544-546.

Kleinman, L.I. and Lorenz, J.M. (1989): Physiology and Pathophysiology of body water and electrolytes. In: Kaplan, L.A. and Pesce, A.J. (eds.): Clinical Chemistry: Theory, Analysis and Correlation. . V Mosby (Toronto) pp. 313-331.
Koter, M., Kedziora, J; Palecz, D; Bartosz, G. and Leykor, W. (1985): Erythrocyte cation content and ATpase activity in Down's syndrome. IRCS Med. Sd. 13:109.

Latner, A.L. (1975): Cantarow and Trumper Clinical Biochemistry, W.B. Saunders and Co., Philadelphia, pp. $355,356,405,792$.

Macdonald, RN. and Good, W. (1971a): Changes in plasma sodium potassium and chloride concentratins in pregnancy and the pueperium, with plasma and serum osmolality. I. Obstet. Gynaec. Brit. Cwlth J, 78; 798-.803 Macdonald, U.N. and Good, W. (1971 b): Changes in plasma total protein, albumin, urea and a - amino nitrogen concentrations in pregnancy and the puerperium. J. Obstet. Gvnaec Br/i. (Cwlih. 78: 912-917. Mulei, C.M. and Daniel R.C.W. (1990): The effects of age on the erythrocyte sodium and potassium concentrations of dairy cows during late pregnancy and early lactation. Vet. Res.Comm. 1-1: 63-70.

Muller, C.M., Daniel, R.C.W. and Green, D. (1988): Changes in erythrocytes $\mathrm{Mg}, \mathrm{Na}$ and $\mathrm{K}$ concentrations in late pregnancy and early lactation and their relationship with subsequent fertility and milk production in dairy cows. J. Vet. Med.

A 35:522-528.

Omotainse, S.0., Anosa V.0. and Falaye, C. (1994): Clinical and biochemical changes in experimental Trypanosoma brucei infection of dogs. Israeli. Vet. Med. 49: 36 - 39

Reitman, S. and Frankel, S. (1957): A colorimetric method for the determination of serum glutamic oxaloacetic and glutamic pyruvic transaminases. Am. .J C/in. Path. 28:56-62, 1957.

Rowlands, G.J., Manston, R; Pocock, R.M. and Dew, S.M. (1975): Relationships between stage of lactation and pregnancy and blood composition in a herd of dairy cows and the influences of seasonal changes in on these relationships. I. Dairy Res. 42: 349-362.

SAS (Statistical Analysis System Procedure Guide (1988): SAS Inst. Cary, N.C. U.S.A.

Sass, M.D; Vorsanger, E. and Spear, P.W. (1964): Enzyme activity as an indicator of red cell age. Cin Chim Acta 10: 21-26.

Sims, E.A.H. and Krantz, K.E. (1958): Serial studies of renal function during pregnancy and puerperium in normal women. .J. Clin. Investigation. 37: 1764-1774

Toro, G. and Ackermann, P.G. (1975): Practical Clinical chemistry. 1st edition Little Brown and Co. Boston.

Vihan, V.S. and Rai, P. (1987): Certain haematological and biochemical attributes during pregnancy, parturition and post parturient periods in sheep and goats. Ind. J. Anim. Sci. 57: 1200-1204

Wilson, O. and Dixon, E. (1991): Erythrocyte cation content and sodium transport in Siberian Huskies. Aiii. I. Vet. J?es. 52: 1427-1432.

Zlarktis, A; Zak, B and Boyle, A.J. (1953): A New method for direct determination of serum cholesterol. J. Lab. (7/ Med. 41: 486. 